\title{
In Vivo Investigation of Genotoxic and Antigenotoxic Po- tential of Hypericum Perforatum Extract in Rats
}

\author{
Selinay Timoçin ${ }^{\mathbf{1}^{*}}$, Hasan Basri İla ${ }^{\mathbf{1}}$ \\ ${ }^{1}$ Çukurova University, Faculty of Science and Letters, Department of Biology, Sarlçam, \\ Adana, Turkey.
}

\begin{abstract}
This study was planned to reveal in vivo genotoxic, antigenotoxic and cytotoxic properties of methanolic extracts of St. John's Wort plant (Hypericum perforatum). The methanol extract of $H$. perforatum was administrated to rats alone or in combination with $\mathrm{N}$ nitrosodimethylamine and Triclosan (positive control). The concentrations of $H$. Perforatum were 20, 100, $500 \mathrm{mg} / \mathrm{kg}$ and administration duration was 30 days. At the end of this period, chromosome aberration test used to determine genotoxic and antigenotoxic effects of $H$. perforatum. In addition, total oxidant and antioxidant levels of peripheral blood serum of rats were determined by spectrophotometric method. According to our result, $H$. perforatum extract did not demonstrate genotoxic effect at concentrations administrated. When compared to the negative control, the percentage of abnormal cells was increased in groups treated with test substance, $N$-nitrosodiethylamine and triclosan together. However, these increases were not as higher as groups treated with $\mathrm{N}$ nitrosodiethylamine plus triclosan (positive control). Even, in groups treated with the test substance additional $\mathrm{N}$-nitrosodiethylamine plus triclosan, the ratio of abnormal cells was inversely proportional to the increase in the concentration. The lowest ratio of abnormal cells was in the group in which the highest concentration of the H. perforatum $(500 \mathrm{mg} / \mathrm{kg})$ was applied. The highest two concentrations of the $\mathrm{H}$. perforatum (100 and $500 \mathrm{mg} / \mathrm{kg}$ ) significantly increased the mitotic index. In the group treated with test substance and positive control together, the mitotic index was even greater. At the same time $100 \mathrm{mg} / \mathrm{kg}$ of $H$. perforatum extract significantly reduced the oxidative stress.
\end{abstract}

Key words: Hypericum Perforatum, N-nitrosodiethylamine, triclosan, cytotoxicity, genotoxicity, rat bone marrow, oxidative stress.

\footnotetext{
*Corresponding Author: Selinay Timoçin, Tel: +90 535510 2395, e-mail: selinaytimocin@ hotmail.com, OR- CID ID: 0000-0002-7746-8571.
} 


\section{Introduction}

Including Hypericum perforatum (St. John's Wort) Around 490 species from Hypericaceae family, are grown in many different regions of the world, and Turkey. It is known as John's wort. During the flowering period, flowers and buds of the plant or all over the ground parts can be collected and used immediately after drying. The John's wort was used in the treatment of mental disorders in Europe and was also a very popular plant in America continent. In folkloric use, the plant's yellow stems are collected and kept in a place where the sunlight is shining until it takes a red colour in the olive oil. This oil is used commonly as a cure for burn injuries and wounds in bedridden patients (1-3). $H$. perforatum is a medicinal plant with antidepressant properties and has antiinflammatory effects such as arachidonate 5-lipoxygenase inhibitor and COX-1 inhibitor $(4,5)$. According to clinical studies, $H$. perforatum has antidepressant properties and has milder side effects (6). It has also been shown that $H$. perforatum had antiviral, anticancer and antiproliferative effects $(7,8)$.

The ethanolic aqueous extract of $H$. perforatum gave negative results in both in vitro and in vivo studies and did not show mutagenic potential (9). In another study, it was reported that $H$. perforatum water extract had protective effect against alkylating DNA damage induced by methylmethanesulfonate (MMS) in colon cancer cell line (HT29) and also increased the repair of alkylated DNA damage (10). In a different in vitro study, hyperforin a constituent of St John's wort extract was found to induce apoptosis by trigerring activation of caspases, and in combination with hypericin, it synergistically exerted cytotoxicity towards human malignant cell lines (11). Methanolic extract of $H$. perforatum and hypericin, the plant's active ingredient, induced apoptosis and long-lasting inhibi- tion of cell growth and decreased phototoxicity $(12,13)$. However, in an investigation of the effects of $H$. perforatum peptide extracts on non- small cell lung carcinoma cells (A549), lung cancer cells (H1299) and HeLa cervical cancer cells, extracts at various concentrations were administrated to cells. It was indicated that $H$. perforatum peptide extract did not have any effect on proliferation activity and growth of tumor in that study (14). Nnitrosodimethylamine (DEN), which is considered a human car- cinogen $(15,16)$ and plays a role in the induction of gastric, esophagus and nasopharyngeal cancers (17). Triclosan [5- chloro-2- (2, 4-ichlorophenoxy) fenol; TCS], a broad spectrum antibacterial agent used in a wide range of synthetic products like soaps, cosmetics, therapeutics and plastics (18). Both of them were used as a positive control in this study. It has been discovered that triclosan significantly accelerates the development of hepatocellular carcinoma (HCC) and acts as a liver tumor promoter when it was used with procarcin- ogen diethylnitrosamine

(DEN). Triclosan treated rats were found to exhibit large increases in tumor variety, size, and incidence when compared with control groups (19).

In this study, chronically (30 days) genotoxic and cytotoxic effects of $H$. perforatum extract alone or in combination with positive control (DEN and triclosan) were investigated in rat 
marrow cells. Furthermore, the effects of $H$. perforatum on oxidative stress in rat peripheral blood were also determined.

\section{Method}

Sprague-Dawley albino rats were used in this study. The animals were 8-12 week old and their weights varied between 180-250 gr. six male rats were used for each group. The animals were provided by Çukurova University Medical Faculty Experimental Medicine Research and Application Center (CUTF-DETAUM) and housed 12-hour light and dim cycle individually in air-conditioned cages (24 $\pm 2^{\circ} \mathrm{C}$ ) rooms. Water and nutrients were provided ad libitum. Experimental studies were conducted upon the approval of animal ethics by the local ethical committee $(12 / 28 / 2015,10)$.

N-Nitrosodiethylamine (CAS No: 55-185), Triclosan (3380-34-5) and Colchicine (CAS No: 64-86-8) were purchased from Sigma-Aldrich.

$H$. perforatum was collected from Mersin, Gözne region on July 2016 and identified by Prof. Necattin Türkmen who is botanic professor in Çukurova University, Department of Biology. The remaining plants from the study are stored in the genetics laboratory of the Biology Department of Çukurova University. Aboveground parts of $H$. perforatum (Yellow centaur) were dried with a lyophilizer. Then 15 grams of each dried tissues were weighed, mixed with $200 \mathrm{~mL}$ of methanol and milled with a laboratory type mill (KINEMATIC MB 800). After that, the mixture was placed in an ultrasonic bath for 45 minutes at $30{ }^{\circ} \mathrm{C}$, centrifuged at $3500 \mathrm{~g}$ for 10 minutes at $20^{\circ} \mathrm{C}$ and filtered through a blotting paper with drying paper. This process was repeated one more time. Then, methanol was evaporated at $40{ }^{\circ} \mathrm{C}$ in a filtrate vacuum evaporator (Polyscience Rotary Vacuum) and finally the remaining extract was dissolved in distilled water.

In the literature, the lowest toxic dose (TDLo) value of $H$. perforatum alcohol extract was reported to be $500 \mathrm{mg} / \mathrm{kg}$ body weight (bw) for oral rat (20). Therefore, the highest concentration inour study was determined as $500 \mathrm{mg} / \mathrm{kg}$. Lower concentrations were also $100 \mathrm{mg} /$ $\mathrm{kg}$ and $20 \mathrm{mg} / \mathrm{kg}$. For each concentration, a total of six mice were treated with test medium via intragastric gavage. The rats were given a single dose of test substance every day for 30 days and then bone marrow cell was harvested (Test group 1). In addition, serum obtained from the peripheral blood of rats was stored to -80 ${ }^{\circ} \mathrm{C}$ conditions up to TAS-TOS measurement.

$\mathrm{N}$-nitrosodimethylamine was dissolved in water and treated to rats intraperitoneal as single dose of $200 \mathrm{mg}$

/ $\mathrm{kg}$ body weight before the $H$. perforatum extract treatments. Triclosan was dissolved in \% 70 ethyl alcohol and was sprayed onto the feed of experimental animals (0.09 $\mathrm{mg}$ Triclosan for $1 \mathrm{~kg}$ meal). In terms ofequal treatment of animals, the animals were housed in different cages. After the end of the treatment period, chromosome preparation and blood serum storage were performed (Test group 2).

Two hours before the chromosome aberration test, colchicine was given to the animals intraperitoneally $(3 \mathrm{mg} / \mathrm{kg}$, bw). The current protocol for testing this study (21) has been modified and used (22). Rats were sacrificed by cervical dislocation then bone marrow was taken 
from femur and transferred to warm physiological solution $(0.9 \% \mathrm{NaCl}, 37$ $\left.{ }^{\circ} \mathrm{C}\right)$. The resulting suspension was centrifuged at 2,000 rpm for $5 \mathrm{~min}$. Supernatant was removed and hypotonic solution $\left(0.4 \mathrm{KCl}, 37^{\circ} \mathrm{C}\right)$ was added to cells and centrifuged for $10 \mathrm{~min}$ in room temparature. Later supernatant was removed by centrifugation and cold fixative (1/3, glacial acetic acid / methanol) was added. Bone marrow cells were fixed at room temperature (24 $\pm 2{ }^{\circ} \mathrm{C}, 20 \mathrm{~min}$ ) and supernatant was removed by centrifugation at the end of the time. Then this process was repeated once more. The fixed cells were dripped onto clean cold slides. Dried slides were stained with 5\% Giemsa and the slides were cover slipped for microscopic evaluation. With this way, permanent slides were prepared.

In order to detect chromosome aberrations, were calculated by examining 100 metaphases for each rat and 600 metaphases for each group. To determine the mitotic index (MI), 3.000 cells per rat and 18.000 cells per group were assessed.

Total oxidant and antioxidant level testing was performed using peripheral blood se- rum. Blood was put in the tubes, centrifuged at $3.000 \mathrm{rpm}$ for 10 min and serum was stored. TOS and TAS values were determined using commercial kits (Rel assay, Turkey). Calculation of the TOS values is based on the oxidation of the divalent iron $\left(\mathrm{Fe}^{+2}\right)$. Existing oxidants oxidize divalent iron (ferrous ion $=\mathrm{Fe}^{+2}$ ) to trivalent iron (ferric ion $=\mathrm{Fe}^{+\mathbf{3}}$ ). The ferric ion forms a coloured complex with the chromium in an acidic medium. This colour intensity, which is proportional to the amount of oxidizing molecules present in the sample, is measured spectrophotometrically. The test is calibrated with hydrogen peroxide and the results are expressed in micromolar hydrogen peroxide equivalent ( $\mu \mathrm{mol}$ equivalent $\mathrm{H} 2 \mathrm{O} 2$ / L) per liter (23).

Determination of TAS values is based on the principle that ABTS (2, 2'-Azino-bis (3-ethylbenzothiazoline-6-sulfonic acid) radical cation is bleached by antioxidants. The results are expressed as mmol Trolox equivalents / L (24).

Oxidative stress index (OSI) was determined using the obtained TOS and TAS values. OSI is calculated by using the following formula:

OSI = TOS / TAS (25-27).

All values were presented as mean \pm standard error (SE). Shapiro-Wilk testwas used to check normal distribution of the data. One-way variance analysis (ANOVA) and post hoc Dunnett test were performed using SPSS software. In comparisons, $\mathrm{p} \leq 0.05$ was considered significant.

\section{Result}

Genotoxic Effects of Hypericum perforatum

In this study, it was found that any concentrations did not significantly increased abnormal cell ratios compared to the negative control group. Also, these levels were significantly lower compared to the test group $2(\mathrm{P}<0.001)$. It was observed that $H$. perforatum had a tendency to reduce the abnormal cell percentage and that effect was mostly apparent in $100 \mathrm{mg} / \mathrm{kg}$ treatment group administered with $H$. perforatum alone (Table 1). Abnormal cell percentage determined in groups in which $H$. perforatum and $\mathrm{N}$-nitrosodiethylamine and triclosan were given together was 
higher than negative control However, all detected abnormalities were significantly lower than the test group 2 $(\mathrm{P}<0.001)$. In this study, it was observed that as $H$. perforatum concentrations increased, abnormal cell ratios were decreased accordingly. Finally, the lowest value of abnormal cell percentage in test group 2 was found at the highest concentration $(500 \mathrm{mg} / \mathrm{kg}$ ) of $H$. perforatum. It was observed that these treatments $(20,100$ or $500 \mathrm{mg} / \mathrm{kg})$ of $H$. perforatum reduced the percentage of abnormal cells caused by the positive control (DEN+T) (Table1).

Table 1: Abnormal Cell Percentage, CA/Cell Ratio and Mitotic Index.

\begin{tabular}{|c|c|c|c|c|c|}
\hline $\begin{array}{l}\text { Test Sub- } \\
\text { stance }\end{array}$ & $\begin{array}{l}\text { Treatment } \\
\text { period } \\
\text { (day) }\end{array}$ & $\begin{array}{c}\text { Cons. } \\
\text { mg/kg b.w. }\end{array}$ & $\begin{array}{l}\text { Abnormal Cell } \\
\text { Percantage } \pm \\
\text { SE }^{\mathbf{b}}\end{array}$ & CA/Cell Ratio \pm SE & $\mathrm{MI} \pm \mathrm{SE}$ \\
\hline $\begin{array}{c}\text { Negative } \\
\text { Control }\end{array}$ & - & 0 & $0.333 \pm 0.211$ & $0.0033 \pm 0.0021$ & $2.61 \pm 0.11$ \\
\hline $\begin{array}{l}\text { Positive } \\
\text { Control }^{\mathrm{a}}\end{array}$ & 30 & $200^{e}$ & $5.167 \pm 0.601$ & $0.0567 \pm 0.0056$ & $3.36 \pm 0.40$ \\
\hline \multirow{3}{*}{$\begin{array}{c}\text { Test } \\
\text { Group } 1\end{array}$} & \multirow{3}{*}{30} & 20 & $0.333 \pm 0.211$ & $0.0033 \pm 0,0021$ & $2.94 \pm 0.37$ \\
\hline & & 100 & $0,167 \pm 0.167$ & $0.0017 \pm 0,0017$ & $4.55 \pm 0.22^{\mathrm{c}}$ \\
\hline & & 500 & $0.333 \pm 0.211$ & $0.0033 \pm 0,0021$ & $5.91 \pm 0.47^{\mathrm{c}}$ \\
\hline \multirow{3}{*}{$\begin{array}{c}\text { Test } \\
\text { Group } 2\end{array}$} & \multirow{3}{*}{30} & $20+200^{\mathrm{e}}$ & $2.167 \pm 0.401^{d}$ & $0.0250 \pm 0,0056^{d}$ & $6.22 \pm 0.22^{d}$ \\
\hline & & $100+200^{e}$ & $1.000 \pm 0.000^{\mathrm{d}}$ & $0.0125 \pm 0.0025^{\mathrm{d}}$ & $7.45 \pm 0.07^{\mathrm{d}}$ \\
\hline & & $500+200^{e}$ & $0.833 \pm 0.307^{\mathrm{d}}$ & $0.0083 \pm 0.0031^{d}$ & $6.50 \pm 0.35^{d}$ \\
\hline \multicolumn{6}{|c|}{$\begin{array}{l}\text { a Positive control: Triclosan }+ \text { N-nitrosodiethylamine } \\
\text { b SE: Standart error } \\
\text { c comparison with negative control is very important }(\mathrm{p} \leq 0.001) \\
\text { d comparison with positive control is very important }(\mathrm{p} \leq 0.001)\end{array}$} \\
\hline
\end{tabular}

\section{Cytotoxic Effects of Hypericum} perforatum

The increase in cell proliferation at all concentrations of $H$. perforatum has manifested itself as an increase in mitotic index. In the group administered with $H$. perforatum alone, the mitotic index, at the highest concentration of $H$. perforatum, was found to be significantly higher than the negative control and positive control $(\mathrm{P} \leq 0.001)$. In the test group 2, the mitotic index was found to be statistically significantly higher than positive control $(\mathrm{P} \leq 0.001)$. It has been determined that the $H$. perforatum showed a synergistic effect when administered with DEN $+\mathrm{T}$
(Table 1). In the literature, it is pointed out that $H$. perforatum had cytotoxic effects in most of the in vitro studies $(28,29)$. In contrast, in our study, we found that $H$. perforatum extract had proliferative effect in vivo. From this point of view, our study is the first to show that $H$. perforatum extract promotes cell division. For this reason, we believe that this property of $H$. perforatum should be supported by additional in vivo studies.

Total Oxidant and Antioxidant Capacity of Hypericum Perforatum

Total oxidant (TOS) and total antioxidant values (TAS) were measured spectrophotometrically in rat blood serum 
in order to detect the oxidative effects. Only one group (100 mg / kg) had significantly lower total oxidant level than the control groups $(\mathrm{p}<0.01)$. In the test group 2, total oxidant levels showed significant reductions (except $100 \mathrm{mg} / \mathrm{kg}$ concentration) (Table 2). Total antioxidant levels were found to be reduced only in group administered with $500 \mathrm{mg} / \mathrm{kg} H$. perforatum + positive control (DEN and triclosan) compared to positive control alone (DEN and triclosan) (Table 2). As a result, it was found that $100 \mathrm{mg} / \mathrm{kg} H$. perforatum decreased the oxidative stress in comparison with the negative control group (Table 2).

Table 2: Total Oxidant and Total Antioxidant in Rat Peripheral Blood Lymphocytes Treated with Hypericum Perforatum Extract at Different Concentrations

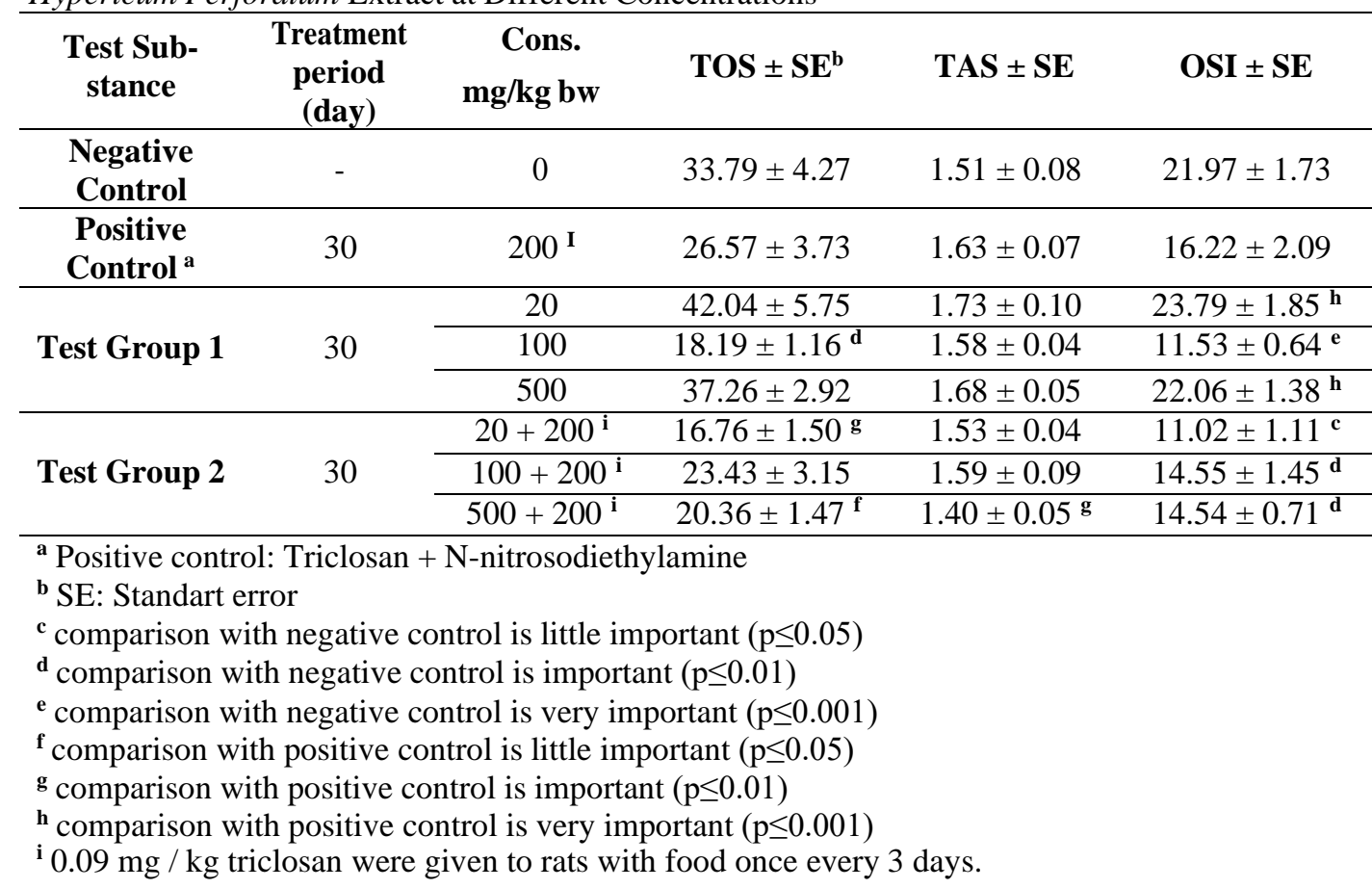

\section{Discussion}

In our study, $H$. perforatum extract significantly reduced the frequency of chromosome aberrations induced by $\mathrm{N}$ nitrosodiethylamine and triclosan in bone marrow cells of healthy rats. In chromosome aberration tests in mouse and chinese hamster bone marrow cells, aqueous methanolic extract of $H$. perforatum was found to have no significant mutagenic effect (9). Some phytotoxins present in $H$. perforatum (cyanogenic glycosides, solanine and chaconine, thujone, and glycyrrhizinic acid) react with many molecules including DNA resulting in toxic effects. One of these effects that cause tumor formation is genotoxic effect (30). In a different study, it has been shown that the nonphotoactivated (non-phototacticized) hypericin did not exhibit mutagenic activity in the Ames test with or without metabolic activation and did not show any protective effect against 9-aminoacridineinduced mutagenicity. In analysis with yeast Saccharomyces Cerevisiae, hypericin did not increase the frequency of mitotic crossing-over or total aberrations 
in the ade (2) locus. Hypericin, while not mutagenic in the Chlamydomonas reinhardtii, has reduced methyl methane sulfonate toxicity and mutagenesis to a small extent. In a chromosome aberration assay using three mammalian cell lines, hypericin did not alter the frequency of structural chromosome aberrations and resulted in no antioxidant effect in the DPPH radical sweep test (31). Similar to our findings, it has been reported that the water extract of $H$. perforatum showed protective effect against alkylating DNA damage induced by methylmethanesulfonate (MMS) and also sup- ported the repair of alkylated DNA damage (10). Resarchers have reported a similar result and it has been found that $H$. perforatum has anti-clastogenic effect against clastogenicity, which is caused by cytotox- ic and mutagenic effect of cyclophosphamide (CYP) in onion meristem cells and rat bone marrow cells (32). In the same study, pretreatment of $H$. perforatum decreased the damage of CYP up to $76 \%$, concurrent treatment decreased 95\% and post-treatment decreased $97 \%$. Antigenotoxic effect of $H$. perforatum on healthy cells is consistent with our findings. In summary, in the majority of genotoxicity studies conducted with the extract of $H$. perforatum, this agent appears to have a protective potential against genotoxic and mutagenic agents. According to the results of this study, $H$. perforatum extract shows a proliferative activity. In contrast to our findings, it has been shown that apoptosis was induced by hypericin in neoplastic human leukemia cell line and thus showed cytotoxic effect (28). In a similar study in which HepG2, HepaRG and WRL-68 cell lines were exposed to $H$. perforatum, hypericin and hyperphosphoric compounds at different concentrations for 24 or 72 hours, these substances were reported to be cytotoxic in the MTT assay (29). In another study, it was reported that $H$. perforatum extract showed neither cytotoxic effect in meristematic cells of Allium cepa L. nor cytotoxic/mutagenic effect in acute treatment of intraperitoneal or subchronic gavage in animal experiments (32). Based on our findings and the literature, these results indicate that the bioactive components of $H$. perforatum show cytotoxic effect on neoplastic cell lines, but do not show such an effect on healthy cells and even proliferative effect.

Our results suggest that although $H$. perforatum extract showed no significant preventive effect on the oxidative stress induced in the blood serum of rats, 100 $\mathrm{mg} / \mathrm{kg}$ concentration of $H$. perforatum extract caused significant reduction in total oxidant status and therefore decreased the oxidative stress level. On the other hand, in parallel with our findings, it has been found that $H$. perforatum extract was effective against apoptosis induced by hydrogen peroxide in PC12 cells (cell line derived from mouse adrenal medulla phaeochromocytoma) and standard extracts of $H$. perforatum may prevent DNA breakdown and cell shrinkage resulting from hydrogen peroxide activity (33). In another study, a flavonoid rich extract of $H$. perforatum was able to effectively treat oxidative stress related neurodegenerative disorders like Alzheimer's and Parkinson's disease (34). Moreover, the ability of $H$. perforatum extract to reduce oxaliplatin induced caspase-3 activity in rat astrocytes was evaluated. The extract showed a significant antioxidant effect and could reduce caspase- 3 activity in rat astrocytes 
(35). In our in vivo study, $100 \mathrm{mg} / \mathrm{kg} H$. perforatum extract showed antioxidant effect.

\section{Conclusion}

On the basis of the data obtained in this study, $H$. perforatum extract was not found to have genotoxic potential. Moreover, it has also been found that this extract had a pronounced antigenotoxic effect. Contrary to the studies in the literature, our findings also pointed toward a proliferative feature of $H$. perforatum. As a result, considering the antigenotoxic and cell division promoting effects of $H$. perforatum, we are of the opinion that $H$. perforatum is an effective agent that can be used in many areas.

\section{Conflict of Interests}

The authors declare that no conflict of interest exists.

\section{Acknowledgements}

This article is produced from a master thesis. This study was funded by Çukurova University Research Fund: FYL-20166300. Thanks to Dr. Taygun Timoçin for his contribution to experimental studies and English editing.

\section{References}

1. Öztürk Y. Testing the antidepressant effects of Hypericum species on animal models. Pharmacopsychiatry. 1997;30(S 2):125-128.

2. Baytop T. Türkiye'de Bitkiler ile Tedavi Geçmiste ve Bugün [Treatment Plant in Turkey; Past and Present]. Nobel Tip Kitabevi, İlaveli İkinci Bask1, İstanbul. Turkish, 1999.

3. Ernst E, Hypericum: the genus Hypericum. CRC Press. 2003.

4. Klemow KM, Bartlow A, Crawford J, et al. Medical Attributes of St. John's Wort (Hypericum perfo- ratum). Herbal Medicine: Biomolecular and Clinical Aspects. I. F. F.
Benzie and S. Wachtel-Galor. Boca Raton (FL), 2011.

5. Wolfle U, Seelinger G, Schempp CM. Topical application of St. John's wort (Hypericum perforatum). Planta Med. 2014; 80(2-3):109-120.

6. Zirak N, Shafiee M, Soltani G, et al. Hypericum perforatum in the treatment of psychiatric and neu- rodegenerative disorders: Current evidence and potential mechanisms of action. J Cell Physiol. 2019; 234(6):8496-8508.

7. Chen H, Muhammad I, Zhang Y, et al. Antiviral Activity Against Infectious Bronchitis Virus and Bioactive Components of Hypericum perforatum L. Front Pharmacol. 2019; 10:1272.

8. Gonenc TM, Ozturk M, Turkseven SG, et al. Hypericum Perforatum L.: An Overview Of The Anticancer Potencies Of The Specimens Collected From Different Ecological Environments. Pakistan J Bot. 2020; 52(3): 1003 1010 .

9. Okpanyi SN, Lidzba H, Scholl BC, et al. Genotoxicity of a standardized Hypericum extract. Arzneimittelforschung. 1990;40(8):851855.

10. Ramos AA, Marques F, Fernandes-Ferreira $M$, et al. Water extracts of tree Hypericum sps. protect DNA from oxidative and alkylating damage and enhance DNA repair in colon cells. Food Chem Toxicol. 2013; 51: 80-86.

11. Hostanska K, Reichling J, Bommer S, et al. Hyperforin a constituent of St John's wort (Hyperi- cum perforatum L.) extract induces apoptosis by triggering activation of caspases and with hypericin synergistically exerts cytotoxicity towards human malignant cell lines. Eur J Pharm Biopharm. 2003; 56(1):121-32.

12. Roscetti G, Franzese O, Comandini A, et al. Cytotoxic activity of Hypericum perforatum L. on K562 erythroleukemic cells: differential effects between methanolic extract and hypericin. Phytoth- er Res. 2004; 18(1):66-72. 13. Schmitt LA, Liu Y, Murphy PA, et al. Reduc- tion in hypericin-induced phototoxicity by Hyperi- cum perforatum extracts and pure compounds. J Photochem Photobiol B. 2006; 85(2):118-130.

14. Tepkeeva II, Aushev VN, Zborovskaya IB, et al. Cytostatic activity of peptide extracts of medici- nal plants on transformed A549, H1299, and HeLa Cells. Bull Exp Biol Med. 2009; 147(1):48-51.

15. Bartsch H., Montesano R. Relevance of nitros- amines to human cancer. Carcinogenesis. 1984; 5(11):1381-1393.

16. Bogovski $\mathrm{P}$ and Bogovski S. Special report animal species in which n-nitroso compounds induce cancer. Int J Cancer. 1981; 27(4):471474.

17. Mirvish SS. Role of N-nitroso compounds (NOC) and N-nitrosation in etiology of gastric, 
esophageal, nasopharyngeal and bladder cancer and contribution to cancer of known exposures to NOC. Cancer letters. 1995; 93(1):17-48.

18. Levy CW, Roujeinikova A, Sedelnikova S, et al. Molecular basis of triclosan activity. Nature. 1999; 398(6726):383.

19. Yueh MF, Taniguchi K, Chen S, et al. The commonly used antimicrobial additive triclosan is a liver tumor promoter. Proc Natl Acad Sci U S A. 2014;111(48):17200-5.

20. Polyplant.

https://www.centerchem.com/Products/DownloadF i le.aspx?FileID=7270) accessed on 28 June 2017.

21. OECD Test No. 475: Mammalian Bone Marrow Chromosomal Aberration Test, OECD Publishing.

22. Timocin $\mathrm{T}$, Ila HB. Investigation of flurbiprofen genotoxicity and cytotoxicity in rat bone marrow cells. Drug Chem Toxicol. 2015;38(3):355-360.

23. Erel O. A new automated colorimetric method for measuring total oxidant status. Clin Biochem. 2005; 38(12): 1103-1111.

24. Erel O. A novel automated direct measurement method for total antioxidant capacity using a new generation, more stable ABTS radical cation. Clin Biochem. 2004; 37(4):277-285.

25. Harma M, Harma M, Erel O. Increased oxida- tive stress in patients with hydatidiform mole. Swiss Med Wkly. 2003;133(41-42):563566.

26. Kosecik M, Erel O, Sevinc E, et al. Increased oxidative stress in children exposed to passive smoking. Int J Cardiol. 2005;100(1):6164.

27. Yumru M, Savas HA, Kalenderoglu A, et al. Oxidative imbalance in bipolar disorder subtypes: a comparative study. Prog Neuropsychopharmacol Biol Psychiatry. 2009; 33(6):1070-1074.

28. Schempp CM, Kirkin V, Simon-Haarhaus B, et al. Inhibition of tumour cell growth by hyperforin, a novel anticancer drug from St. John's wort that acts by induction of apoptosis. Oncogene. 2002; 21(8):1242.

29. Silva SM, Martinho A, Moreno I, et al. Effects of Hypericum perforatum extract and its main bio- active compounds on the cytotoxicity and expression of CYP1A2 and CYP2D6 in hepatic cells. Life Sci. 2016; 144:30-6.

30. Rietjens IM, Martena MJ, Boersma MG, et al. Molecular mechanisms of toxicity of important food-borne phytotoxins. Mol Nutr Food Res. 2005;49(2):131-158.

31. Miadokova E, Chalupa I, Vlckova V, et al. Genotoxicity and antigenotoxicity evaluation of non-photoactivated hypericin. Phytother Res. 2010;24(1): 90-5.

32. Peron AP, Mariucci RG, de Almeida IV, et al. Evaluation of the cytotoxicity, mutagenicity and antimutagenicity of a natural antidepressant, Hypericum perforatum L. (St. John's wort), on vegetal and animal test systems. BMC Complement Altern Med. 2013; 6(13):97.

33. $\mathrm{Lu} \mathrm{YH}, \mathrm{Du} \mathrm{CB}, \mathrm{Liu} \mathrm{JW}$, et al. Neuroprotective effects of Hypericum perforatum on trauma induced by hydrogen peroxide in PC12 cells. Am J Chin Med. 2004; 32(3):397-405.

34. Zou YP, Lu YH, Wei DZ. Protective effects of a flavonoid-rich extract of Hypericum perforatum

L. against hydrogen peroxide-induced apoptosis in PC12 cells. Phytother Res. 2010;24 Suppl $1: 6-10$

35. Cinci L, Di Cesare Mannelli L, Maidecchi A, et al. Effects of Hypericum perforatum extract on oxaliplatin-induced neurotoxicity: in vitro evalua- tions. Zeitschrift fur Naturforschung. C, Journal of Biosciences. 2017; 72:219-226. 